\title{
Evidence of clonal variants of Helicobacter pylori in three generations of a duodenal ulcer disease family
}

\author{
C U Nwokolo, J Bickley, A R Attard, R J Owen, M Costas, I A Fraser
}

Departments of Gastroenterology and Surgery, Walsgrave Hospital, Coventry C U Nwokolo A R Attard I A Fraser

National Collection of Type Cultures, Central Public Health

Laboratory, Colindale, London

J Bickley

R J Owen

M Costas

Correspondence to: Dr C U Nwokolo MRCP Gastroenterology Unit, Walsgrave Hospital, Clifford Bridge Road, Coventry CV2 2DX.

Accepted for publication 2 March 1992

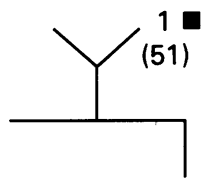

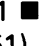

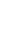

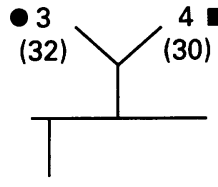

(42)

\begin{abstract}
Nine members of a family with a high incidence of duodenal ulcer disease were studied by interview, examination of hospital records, endoscopy, and antral biopsy. Helicobacter pylori was confirmed by CLO test, histology and culture. DNA extraction from pure isolates of $\boldsymbol{H}$ pylori was possible in six family members and strain typing was performed by restriction fragment length polymorphism. DNA restriction digestion was followed by vacublotting and then DNA hybridisation, using a cDNA probe complimentary to $H$ pylori rRNA cistrons. Eight of the nine family members were $H$ pylori positive by CLO test and histology. Five had duodenal ulcer disease. Three family members (one from each generation) harboured clonal variants of a single parent strain of $\boldsymbol{H}$ pylori but only two had duodenal disease. The other three members harboured different strains. Intrafamilial clustering of clonal variants of $\boldsymbol{H}$ pylori occurs in some duodenal ulcer disease families. Family members however, may develop duodenal disease irrespecitve of the colonising strain.
\end{abstract}

(Gut 1992; 33: 1323-1327)
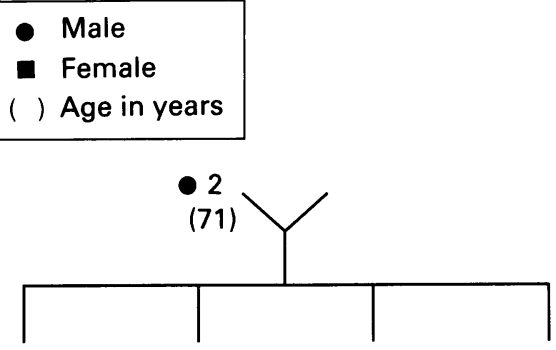

$(30)$

80

(12)

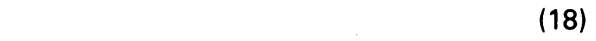

The microaerobic bacterium Helicobacter pylori, is widely accepted as an important cause of gastritis ${ }^{1}$ and infections are strongly associated with peptic ulcer disease ${ }^{2}$ and gastric cancer. ${ }^{3}$ 'The gastrin link't5 and the "leaking roof" are some of the hypotheses proposed to explain the pathogenic link between $H$ pylori and duodenal ulcer disease. Pathogenicity mechanisms of $H$ pylori are poorly understood, but the existence of ulcerogenic strains of this bacterium may explain why only a minority of patients harbouring the organism develop duodenal ulcer disease. Certain virulence factors produced by $H$ pylori have been identified and include a vacuolating, cytopathic agent ${ }^{7}$ and a protein that inhibits rabbit parietal cell acid secretion in vitro. ${ }^{8} H$ pylori strains positive for a $120-\mathrm{KDa}$ protein have recently been described in duodenal ulcer patients. ${ }^{9}$

Evidence is accumulating from DNA fingerprinting that each infected individual harbours a unique strain of $H$ pylori ${ }^{10}$ although the reason for this diversity is unknown. As 20 $50 \%$ of duodenal ulcer patients have a positive family history, " it would be of interest to explore the hypothesis that familial peptic ulcer disease is the cluster effect of a virulent, ulcerogenic strain of $H$ pylori transfecting family members.

\section{Methods}

\section{PATIENTS}

The extended family studied has been recognised in the Coventry area for up to 20 years. Scrutiny of hospital records revealed that during that period, the majority of family members had presented to the Walsgrave Hospital with duodenal ulceration or its complications.

The matriachial head of the family (Fig 1, subject 1) provided a comprehensive family history. There were 25 family members aged over 10 years. Fourteen members lived in the Coventry area, the remainder living in Scotland or Australia. The 14 members living in the area were invited for interview and subsequent endo-

Figure 1: Familial relationships among nine members of three generation $(I, I I, I I I)$ of a duodenal ulcer disease family, with age and sex.

\begin{tabular}{|c|c|c|c|c|c|c|c|}
\hline Subjects & $\begin{array}{l}\text { Clo } \\
\text { test }\end{array}$ & Histology & $\begin{array}{l}\text { Duodenal } \\
\text { ulcer }\end{array}$ & $\begin{array}{l}\text { Plasma gastrin } \\
\text { (ng/litre) }\end{array}$ & $\begin{array}{l}\text { H pylori } \\
\text { isolation }\end{array}$ & $\begin{array}{l}\text { BamHI Total } \\
\text { digest pattern }\end{array}$ & $\begin{array}{l}\text { BamHI } \\
\text { ribopattern }\end{array}$ \\
\hline \multicolumn{8}{|c|}{ Generation I } \\
\hline 1 & + & + & - & 34 & + & 1 & $\mathrm{CO}-1$ \\
\hline 2 & + & + & + & 181 & + & $2 a$ & $\mathrm{CO}-2$ \\
\hline \multicolumn{8}{|c|}{ Generation II } \\
\hline 3 & + & + & + & 35 & + & 3 & $\mathrm{CO}-3$ \\
\hline 4 & - & - & - & 39 & - & na & na \\
\hline 5 & + & + & - & 114 & - & na & na \\
\hline 6 & + & + & + & 177 & + & 4 & $\mathrm{CO}-4$ \\
\hline 7 & + & + & - & 71 & + & $2 \mathrm{~b}$ & nt \\
\hline \multicolumn{8}{|c|}{ Generation III } \\
\hline 8 & + & + & + & 131 & - & na & na \\
\hline 9 & + & + & + & 199 & + & $2 c$ & $\mathrm{CO}-2$ \\
\hline
\end{tabular}




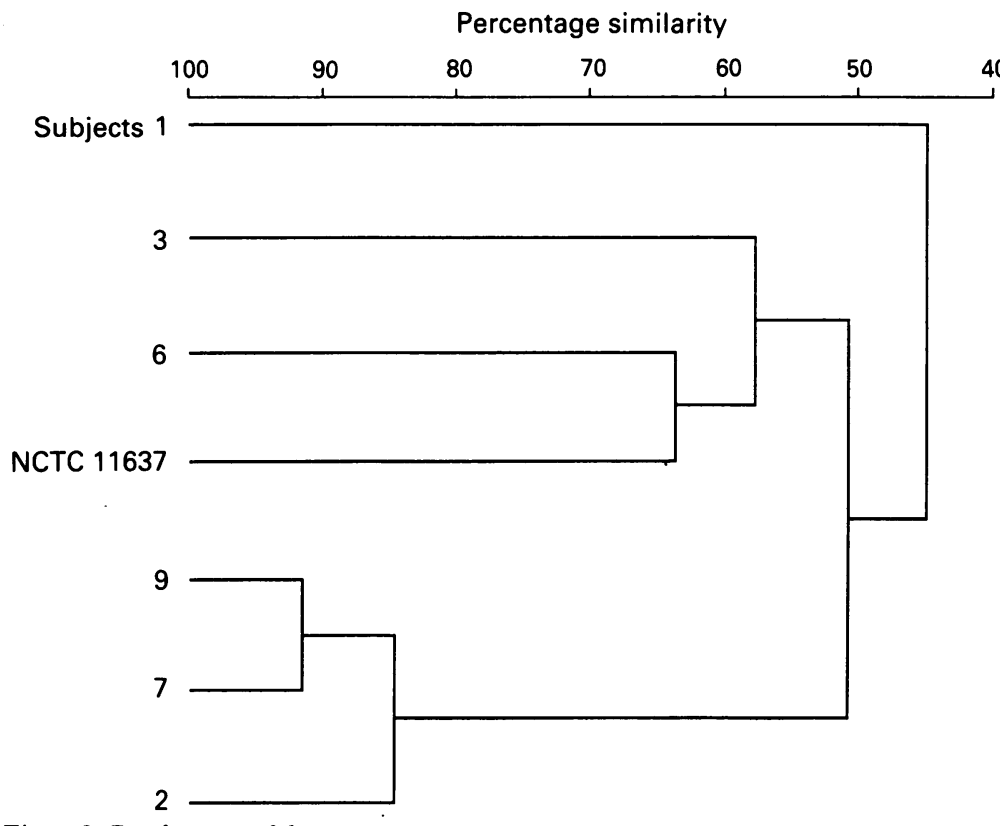

Figure 2: Dendrogram of the cluster analysis to show similarities based on the total DNA digest patterns of Helicobacter pylori isolates from subjects 1, 2, 3, 6, 7, and 9 , and the type strain NCTC 11637. The numbers on the horizontal axis indicate the percentage similarities as determined by the Dice correlation coefficient. scopy. Only nine members eventually participated in the study. The other five either declined to participate or had other commitments. Of the 11 family members living outside the Coventry area, only two could be contacted. Both declined to participate in the study.

\section{FAMILY HISTORY}

A family history was obtained by direct interview of the patients and examination of their hospital record (Table, Fig 1). The following were recorded: (a) Date and method of diagnosis of duodenal ulcer disease. (b) Complications (gastrointestinal bleed, perforations, pyloric stenosis). (c) Indications for and nature of gastric surgery (undersewing of ulcer, vagotomy and drainage). (d) Drugs within the preceding six months ( $\mathrm{H} 2$ blockers, antibiotics, bismuth, nonsteroidal antiinflammatory drugs). (e) Concurrent illnesses (other inherited disease). (f) Patients' date of birth and body weight. (g) Smoking.

PLASMA GASTRIN, ELECTROLYTES AND CALCIUM Before endoscopy, blood $(10 \mathrm{ml})$ was taken from an antecubital vein, transferred into a lithium heparin tube and centrifuged. Plasma was decanted into a $10 \mathrm{~mm}$ diameter plastic tube and immediately frozen to $-20^{\circ} \mathrm{C}$. Plasma gastrin was measured by radioimmunassay at the Department of Biochemistry, East Birmingham General Hospital. A further blood sample was taken for routine biochemistry and calcium.

\section{UPPER GASTROINTESTINAL ENDOSCOPY}

Endoscopy was performed after an overnight fast. Before each examination, endoscopes were thoroughly cleaned mechanically with detergent as recommended by the British Society of Gastroenterology. ${ }^{12}$ Endoscope channels were filled with $2 \%$ gluteraldehyde and then immersed in the same disinfectant for a minimum of 20 minutes. Thorough rinsing was then performed. A single biopsy forcep was used for each patient to prevent transfer of $H$ pylori between patients. Duodenal ulceration was recorded only when an ulcer crater of at least $5 \mathrm{~mm}$ diameter was observed. Pyloroduodenal scarring, antritis, duodenitis and gastric anatomical abnormalities from previous surgery were also recorded.

\section{BIOPSY}

Four antral biopsies were taken from each patient. One was used for a CLO test (Delta West limited, Bentley, Western Australia) and one was transferred into $10 \% \mathrm{w} / \mathrm{v}$ formaldehyde for histology. The other two were transferred separately into two bijoux containing $H$ pylori selective enrichment (SE) medium ${ }^{13}$ and were number coded randomly to ensure that culture and DNA analysis were performed blind.

\section{CULTURE}

Antral biopsy specimens were placed in $5 \mathrm{ml}$ of selective enrichment medium and incubated at $37^{\circ} \mathrm{C}$ on a gyratory platform $(150 \mathrm{rpm})$ in a Variable Atmosphere Incubator (Don Whitley Scientific Ltd, Shipley, Yorks, UK) under microaerobic conditions ( $5 \%$ oxygen, $5 \%$ carbon dioxide, $2 \%$ hydrogen, $88 \%$ nitrogen). A sample from each flask was subcultured onto Oxoid brain heart infusion agar, supplemented with 5\% horse blood and 1\% Isovitalex after 48 hours. Positive growth was identified by Gram stain and production of urease, and cultures were preserved at $-196^{\circ} \mathrm{C}$ on glass beads in Oxoid nutrient Broth No. 2 containing (v/v) glycerol.

\section{DNA DIGESTION AND ELECTROPHORESIS}

$H$ pylori chromosomal DNA was isolated using the guanidium thiocyanate reagent method. ${ }^{14}$ The purified DNA was incubated with 11 endonucleases (HaeIII, HindIII, EcoRI, PvuII, PstI, BamIII, SacI, ApaI, StuI, HpaII, MspI) according to the conditions recommended by the manufacturer (Northumbria Biologicals Limited, UK). DNA samples (5 $\mu \mathrm{g})$ were digested for four hours at $37^{\circ} \mathrm{C}$. The digested DNA was electrophoresed at $30 \mathrm{~V}$ or 16 hours in a horizontal $0.8 \%(\mathrm{w} / \mathrm{v})$ agarose gel in a buffer containing $89 \mathrm{mM}$ Tris hydrochloride, $89 \mathrm{mM}$ boric acid, and $2 \mathrm{mM}$ disodium ethylenediaminetetra-acetic acid (EDTA) (pH 8·3). After electrophoresis, the gels were stained with ethidium bromide and photographed.

\section{COMPARISON OF DIGEST PATTERNS BY} DENSITOMETRY

Patterns were scanned and analysed with a laser densitometer interfaced to a Compaq Deskpro 386 microcomputer. Profiles were compared by band matching, using the Dice correlation coefficient. ${ }^{\text {is }}$ Strains were then clustered and a dendrogram plotted (Fig 2).

\section{VACUBLOTTING AND HYBRIDISATION}

A biotinylated cDNA probe was prepared from $H$ pylori NCTC (National Collection of Type 


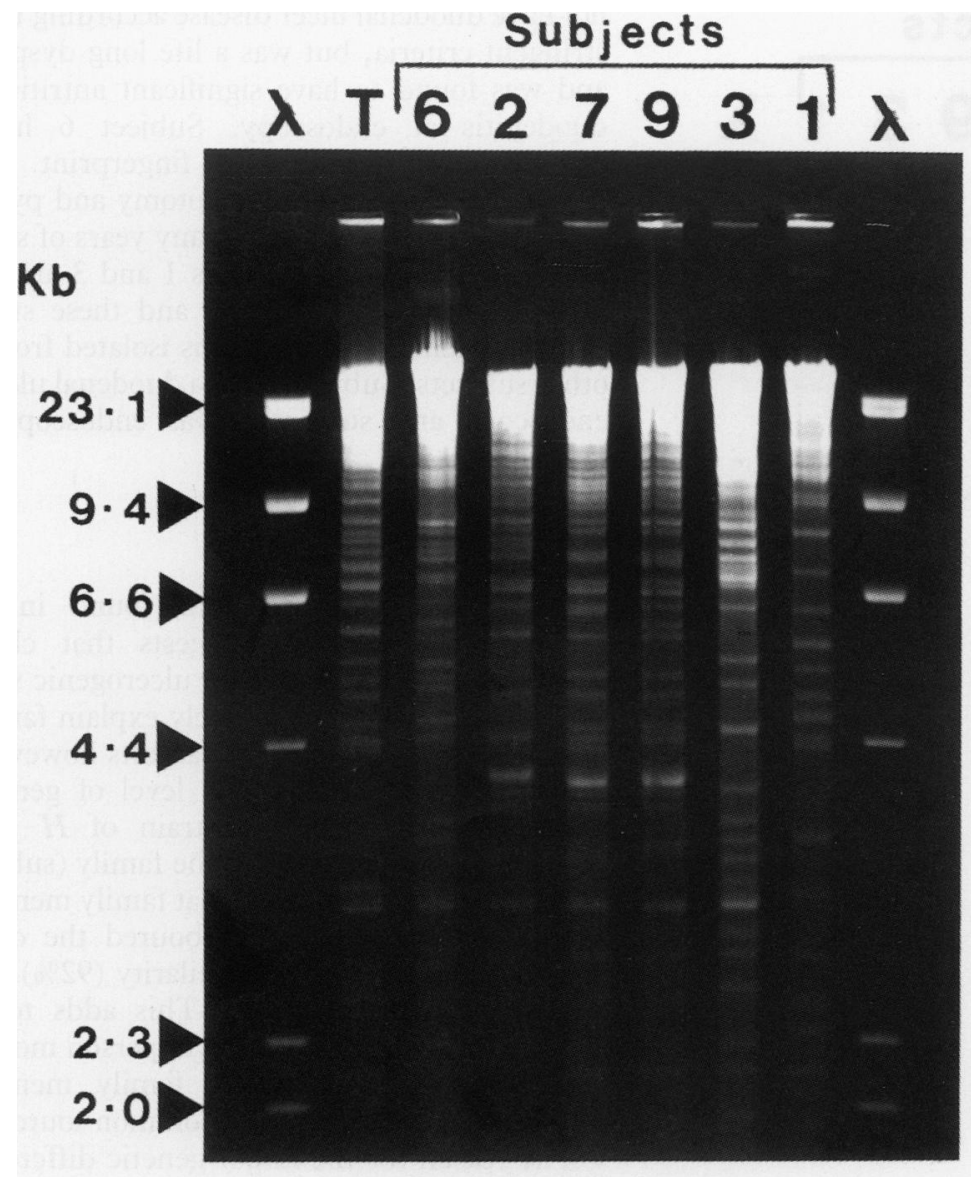

$\lambda$; Mol. Wt. Markers

\section{T ; Type Strain (NCTC 11637)}

Figure 3: Agarose gel electrophoresis of Bam HI digest fragments of chromosomal DNA from Helicobacter pylori. Sizes indicated are for bacteriophage $\lambda$ Hind $I I I$ digest $(\lambda)$. Subjects are numbered according to text and $\mathrm{H}$ pylori NCTC 11637 (type strain) was included as a reference.

Moloney mouse leukaemia virus reverse transcriptase (Gibco-BRL). Biotinylation was achieved by the incorporation of biotin-16dUTP. ${ }^{16}$ After electrophoresis and photography, the gels were transferred to nylon membranes (Hybond-N, Amersham International) by means of vacublotting (Vacu-Gene XL, Pharmacia
(Fig 1). Their median age was 42 years (range 12-71). There were three females and six males. All the males (except for the 12 and 18 year olds in generation III) had smoked, but none had smoked in the year preceding the study.

PLASMA GASTRIN, ELECTROLYTES AND CALCIUM Mildly raised plasma gastrin were observed in five subjects (Table). Subject 9 was taking omeprazole and subject 8 was taking an $\mathrm{H}_{2}$ blocker. Two subjects (2 and 6) had undergone vagotomy. Serum electrolytes and calcium were normal.

\section{DUODENAL ULCER DISEASE}

A diagnosis of duodenal ulcer disease was accepted only if a family member was found to have an acute duodenal ulcer at the study endoscopy or had a history of gastric surgery performed for intractable duodenal ulceration. Duodenal ulcer disease was confirmed in five subjects $(2,3,6,8$ and 9). Several other family members had a history of duodenal ulceration but were not available for inclusion in the study. All the subjects with duodenal ulcer disease had become symptomatic in the first or second decade of life. In all cases confirmatory evidence of active duodenal ulceration had been obtained by the end of the third decade, except for the 71 year old man (subject 2), in whom confirmation was obtained in the fifth decade.

\section{H PYLORI STATUS}

Eight of the nine $(90 \%)$ family members were positive for $H$ pylori by CLO test and histology (Table). The one negative subject (subject 4) was a woman (age 30 ) in the second generation. Although she was endoscopically normal, her 12 year old son (subject 8) had confirmed duodenal ulcer disease from the age of eight, requiring maintenance treatment with an $\mathrm{H}_{2}$ blocker. LKB Biotechnology). The membranes were then hybridised by standard procedures for 16 hours at $42^{\circ} \mathrm{C}$ using the hybridised probe detected colorimetrically using a nonradioactive detection kit - BluGENE (Gibco-BRL).

\section{ETHICS}

Ethical approval was obtained from the Coventry and Warwickshire Postgraduate Medical Ethics Committee as part of a larger epidemiological study. Informed consent was obtained from all family members except for the 12 year old. In his case an endoscopy was indicated for the investigation of abdominal pain. His mother provided consent.

\section{Results}

Nine family members representing three generations (I, II, III) participated in the study

\section{ISOLATION AND DNA FINGERPRINTING OF} H PYLORI

Successful isolation of pure cultures of $H$ pylor was possible in six of the nine subjects studied. One family member (subject 4 ) was negative for $H$ pylori (confirmed by CLO test and histology). In one member (subject 5) unsuccessful isolation was caused by non- $H$ pylori contaminants. Two biopsies were obtained from subject 8 (12 years old) for histology and CLO test before endoscopy was abandoned for technical reasons, and ethical considerations precluded a second endoscopy.

Subjects 2, 7, and 9, from whom $H$ pylori had been successfully isolated, harboured strains with similar but not completely identical DNA fingerprints (Figs 3, 4). The Bam HI restriction digest patterns of these three strains differed only in one or two minor bands, whereas all the other strains in the study were very different (Fig 3). All isolates were designated a DNA type based of their BamHI total digest patterns. Subjects 2,7 , and 9 were designated as subtypess $2 \mathrm{a}, 2 \mathrm{~b}$, and $2 \mathrm{c}$ respectively, as their digest 


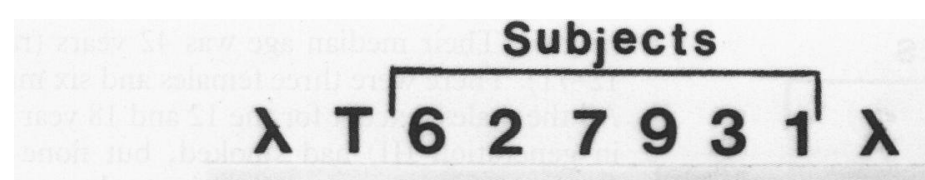

$\mathbf{K b}$

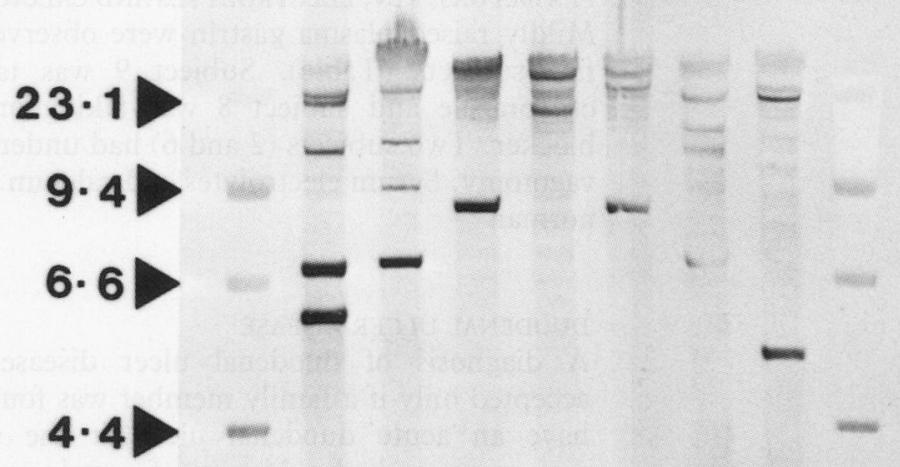

2.3)

\section{$\lambda$; Mol.Wt. Markers}

Figure 4: The rRNA gene

\section{T; Type Strain (NCTC 11637)}

patterns (ribopatterns) for Bam $H I$ digests of chromosomal DNA probed with biotinylated $c D N A$ from

Helicobacter pylori NCTC 11638. Sizes indicated are for bacteriophage

$\lambda$ Hind $I I I$ digest $(\lambda)$. Subjects are numbered according to text and $\mathrm{H}$ pylori $N C T C$ 11637 (type strain) was included as a reference. patterns were very similar (Table, Fig 3). The dendrogram in Figure 2 illustrates the similarities between the Bam HI digest patterns obtained for all subjects. Similarities were obtained using band matching and calculation of the Dice coefficient. Isolates from subjects 2,7 , and 9 clustered at a similarity of $85 \%$, with isolates from subjects 7 and 9 being most closely related at a similarity of $92 \%$. All other subjects $(1,3,6)$ clustered at similarities of less than $60 \%$.

Less information was available from the $B a m \mathrm{HI}$ ribopatterns obtained after hybridisation with the cDNA probe, because few bands were present. Different ribopatterns were obtained for subjects 1, 3, and 6, however, (Fig 4). Subjects 2 and 9 had the same ribopattern (Table, Fig 4), with a common band of molecular weight $8.8 \mathrm{~kb}$. Subject 7 did not, however, have this band.

Results with other endonucleases showed that DNA from $H$ pylori isolates from subjects 2,7 , and 9 shared the unusual characteristic of being undigested by enzymes which commonly digest DNA from $H$ pylori strains, namely HaeIII and HindIII.

Subjects 2 and 9 had duodenal ulcer disease; one had a vagotomy and drainage procedure, the other had persistent duodenal ulceration despite continuous omeprazole treatment. Subject 7 did not have duodenal ulcer disease according to our stringent criteria, but was a life long dyspeptic and was found to have significant antritis and duodenitis at endoscopy. Subject 6 had a completely different DNA fingerprint. This subject had undergone a vagotomy and pyloroplasty at age 26 years after many years of severe duodenal ulceration. Subjects 1 and 3 also had different strains of $H$ pylori and these strains were different from the strains isolated from all other subjects. Subject 3 had a duodenal ulcer at endoscopy and subject 1 was endoscopically normal.

\section{Discussion}

The diversity of the strains found in this duodenal ulcer family suggests that cluster infection by a single putative ulcerogenic strain of $H$ pylori does not completely explain familial peptic ulcer disease. Clonal variants however, that is, isolates with a high level of genomic relatedness, of the same strain of $H$ pylori colonised three members of the family (subjects 2,7 , and 9). It is of interest that family members (subjects 7 and 9) who harboured the clonal variants with the highest similarity $(92 \%)$ were only one generation apart. This adds to the evidence supporting a person to person mode of transmission. Alternatively, family members may become infected from a common source.

The reason for the minor genetic differences between these clonal variants is unknown. It may represent a tendency to spontaneous genomic rearrangement which may be in the nature of $H$ pylori. Marked genomic heterogeneity is already a recognised characteristic of this bacterium. From our experience, in applying the technique of DNA fingerprinting to strain typing of over 500 isolates of $H$ pylori, ${ }^{15}{ }^{17}$ no two patients were found to harbour $H$ pylori strains with such marked similarity as observed in subjects 2,7 , and 9. Indeed, the small amount of variation between the digest patterns of these three subjects was consistent with the observed variation within multiple isolates from single patients. ${ }^{17}$

Further evidence for the general similarities of these three isolates was obtained from results with other restriction enzymes. DNA from $H$ pylori isolated from subjects 2,7 , and 9 were unusual in not being digested by HaeIII or HindIII. These enzymes would normally digest DNA obtained from the majority of $H$ pylori isolates.

Clustering of $H$ pylori among relatives of infected individuals has been widely reported. ${ }^{18}$ Graham et al recently described the influence of age, sex, social class, and race on the prevalence of $H$ pylori in a western population. ${ }^{19}$ One preliminary report has found a single strain of $H$ pylori clustering in a duodenal ulcer family of eight members. ${ }^{20}$ This report was, however, based solely on total digest patterns obtained with a single restriction enzyme. Another report has described identical strains of $H$ pylori colonising two pairs of mentally subnormal children living in close proximity. ${ }^{21}$

In this study we found eight of nine family members colonised by $H$ pylori. Because the colonising strains were not all identical, this 
suggests that family members may be independently susceptible to $H$ pylori infection.

The development of duodenal ulcer disease in family members seemed independent of the colonising strain. Even among the three family members colonised by clonal variants of the same strain, only two members had duodenal ulcer disease. One was apparently free of disease.

Some genetic subtypes of duodenal ulcer disease were proposed before the rediscovery of $H$ pylori.' A duodenal ulcer family with raised serum hyperpepsinogen 1 concentration inherited as an autosomal dominant trait has been described. ${ }^{22} \mathrm{~A}$ majority of duodenal ulcer patients, however, have raised serum pepsinogen $1 .{ }^{23}$ In addition there is some preliminary evidence to suggest that gastric colonisation with $H$ pylori is associated with raised serum pepsinogen 1 and that the eradication of $H$ pylori returns this towards normal. ${ }^{2+}$

A duodenal ulcer family with accelerated gastric emptying has also been described ${ }^{25}$ but recent data suggest that gastric colonisation with $H$ pylori may modify antroduodenal motility. ${ }^{26}$ Data from the pre $H$ pylori family studies of duodenal ulcer disease should now be reviewed and recent knowledge about $H$ pylori factored into conclusions derived from those studies. The hypotheses derived from those studies should be reassessed.

Mildly raised fasting gastrin concentrations were observed in family members who were taking antisecretory drugs or who had had a vagotomy. There was no clinical or biochemical evidence to suggest that this family had multiple endocrine adenomatosis or other hypergastrinaemic state.

In general, only limited conclusions may be derived from single family studies. Reports of family studies in which $H$ pylori strains have been characterised by molecular biology techniques, however, are infrequent in the medical literature. This study supports the observations of Drumm et $a l^{18}$ that $H$ pylori clusters in some duodenal ulcer families. If gastric colonisation with $H$ pylori precedes duodenal ulceration in all cases, then it may be that duodenal ulcer family members are simply more prone to $H$ pylori infection than members of the general population. The colonising strain of $H$ pylori did not seem to influence the development of duodenal ulcer disease in family members. Intrafamilial clustering of clonal variants arising from a common parent strain of $H$ pylori may occur. An undefined tendency to duodenal ulceration may be inherited in some duodenal ulcer families. Subsequent colonisation with most strains of $H$ pylori promotes this tendency, resulting in active duodenal ulceration.

Sister De Souza and the staff of the Walsgrave Hospital endoscopy unit assisted in the endoscopic procedures. JB is indebted to the Procter and Gamble Company (Cincinnati, Ohio, USA) for financial support.
1 Warren JR, Marshall B. Unidentified curved bacilli on gastric epithelium in active chronic gastritis. Lancet $1983 \mathrm{i}: 1273-5$. Graham DY. Campylobacter pylori and peptic ulcer disease. Gastroenterology 1989; 96: 614-25.

3 Forman D, Newell DG, Fullerton F, Yarnell JWG, Stacey, $\mathrm{AR}$, Wald $\mathrm{N}$, et al. Association between infection with Helicobacter pylori and risk of gastric cancer: evidence from a prospective investigation. $B M \mathcal{F}$ 1991; 302 1302-5.

4 Smith JTL, Pounder RE, Nwokolo CU, Lanzon-Miller S Evans DG, Graham DY. Inappropriate hypergastrinaemi in asymptomatic healthy subjects infected with Helicobacter pylori. Gut 1990; 31: 522-5.

5 Levi S, Beardshall K, Playford R, Ghosh P, Haddad G, Calam J. Campylobacter pylori and duodenal ulcers: the gastrin link. Lancet 1989; i: 1167-8.

6 Goodwin CS. Duodenal ulcer, Campvlobacter pylori and the "leaking roof" concept. Lancet 1989; ii: 1467-9.

7 Figura N, Gugliemetti P, Rossolini A, Barberi A, Cusi G Musmanno RA, et al. Cytotoxin production by Campylobacter pylori strains isolated from patients with peptic ulcers and from patients with chronic gastritis only. $f$ Clin Microbiol 1989; 27: 225-6.

8 Cave DR, Varges M. Effect of Campylobacter protein on acid secretion by parietal cells. Lancet 1989; ii: 187-9.

9 Crabtree JE, Taylor JD, Wyatt JI, Heatley RV, Shallcross TM, Tompkins DS, et al. Mucosal IgA recognition of Helicobacter pylori $120 \mathrm{KDa}$ protein, peptic ulceration and gastric pathology. Lancet 1991; 338: 332-5.

10 Owen RJ, Bickley J, Costas M, Morgan DR. Genomic variation in Helicobacter pylori: application to identification variation in Helicobacter pylort: application to identification
of strains. Scand $\mathcal{F}$ Gastroenterol 1991; 26 (suppl 181): of strains.

11 McConnell RB. Peptic ulcer: early genetic evidence - families, twins and markers. In: Rotter JI, Samloff IM, Rimoin DI eds. The genetics and heterogeneity of common gastrointestinal disorders. New York: Academic Press, 1989; 31 .

12 Weller IVD. Cleaning and disinfection of equipment for gastrointestinal flexible endoscopy: interim recommen dations of a working party of the British Society of Gastroenterology. Gut 1988; 29: 1134-51.

13 Morgan DR, Mathewson JJ, Freedman R, Kraft WG Evaluation of a selective enrichment technique for the Evaluation of a selective enrichment technique for the
isolation of Campylobacter pylori. FEMS Microbiol Lett 1990; 66: 303-6.

14 Pitcher DG, Saunders NA, Owen RJ. Rapid extraction of bacterial genomic DNA with Guanidium thiocyanate. Let Appl Microbiol 1989; 8: 151-6.

15 Costas M, Owen RJ, Bickley J, Morgan DR. Molecula techniques for studying and epidemiology of infection by Helicobacter pylori. Scand $\mathcal{F}$ Gastroenterol 1991; 26 (supp 181): $20-32$.

16 Pitcher DG, Owen RJ, Dyal P, Beck A. Synthesis of a biotinylated probe to detect ribosomal cistron in Providencia stuartii. FEMS Microbiol Lett 1987; 48

17 Owen RJ, Fraser J, Costas M, Morgan DD, Morgan DR bacter pylori before and after treatment. $\mathcal{F}$ Clin Pathol 1990; 43: $646-9$.

18 Drumm B, Perez-Perez GI, Blaser MJ, Sherman P. Intrafamilial clustering of Campylobacter pylori infection. $N$ Eng F Med 1990; 322: 359-63.

19 Graham DY, Malaty HM, Evans DG, Evans DJ (junior) Klein PD, Adam E. Epidemiology of Helicobacter pylori in an asymptomatic population in the United States. Gastroenterology 1991; 100: 1495-501.

20 Rauws EAJ, Langenberg W, Oudbier J, Mulder CJJ, Tytgat GNJ. Familial clustering of peptic ulcer disease colonised with $C$ pylori of the same DNA composition. Gastroenterology 1989; 96: A409.

21 Vincent P, Pernes P, Beju A, Gottrand F, Husson MA Leclerc $\mathrm{H}$, et al. Helicobacter pulori in cohabiting children. Lancet 1991; 337: 848.

22 Rotter JI, Stones JQ, Samloff IM, Richardson CJ, Gurskey $\mathrm{JM}$, Walsh JH, et al. Duodenal ulcer disease associated with elevated pepsinogen 1. An inherited autosomal dominan disorder. NEngl F Med 1979; 300: 53-5.

23 Tanaka Y, Mine K, Nakai Y, Mishima N, Nakagawa T. Serum pepsinogen $l$ concentrations in peptic ulcer patients in relation to ulcer location and stage. Gut 1991; 32 849-52.

24 Chittajalu RS, Dorian CA, McColl KEL. Serum pepsinogen 1 in duodenal ulcer - the effect of eradication of $H$ pulori and correlation with serum gastrin and antral gastritis. Gut 1990 31: Al199.

25 Rotter JI, Rubin R, Meyer JH, Samloff MI, Rimoin D. Rapid gastric emptying - an inherited pathophysiologic defect in gastric emptying - an inherited pathophysiolog
duodenal ulcer. Gastroenterology 1979; 76: 1229 .

26 Testoni RA, Bagnolo F, Passeratti S, Fanti L, Sorghi M. Masci E, et al. Campylobacter pylori infection correlates with more severe interdigestive antro-duodenal motor impairment in subjects with chronic gastritis. Gastroenterology 1990; 98: A137. 